\title{
Improving Students' Literacy Skills in Learning Physical Education, Sports and Health through Zoom Meetings
}

\author{
Intan Risky Nur Apristi ${ }^{1}$, Rina Maryanti2, ${ }^{2 *}$ \\ ${ }^{1}$ Departemen Ilmu Keolahragaan, Universitas Pendidikan Indonesia, Indonesia \\ ${ }^{2}$ Departemen Pendidikan Khusus, Universitas Pendidikan Indonesia, Indonesia \\ *Corresponding author: rina.maryanti@upi.edu
}

\begin{abstract}
Abstrak: Di era pandemi saat ini, pembelajaran antara guru dan siswa dirasa kurang efektif karena kegiatan belajar mengajar berlangsung di rumah. Kegiatan pengabdian masyarakat dalam bentuk Kuliah Kerja Nyata Tematik yang diuraikan dalam makalah ini bertujuan meningkatkan minat siswa dalam belajar, sekaligus memudahkan para guru, siswa dan orang tua walaupun proses pembelajaran berlangsung di rumah. Kegiatannya berupa pembelajaran pendidikan jasmani olahraga dan kesehatan yang dilakukan secara daring melalui aplikasi zoom meeting yang menekankan pada literasi. Metode dalam kegiatan pengabdian kepada masyarakat ini menggunakan penelitian deskriptif kuantitatif dengan teknik random sampling serta menggunakan desain pretest-posttest. Hasil kegiatan menunjukan adanya peningkatan yang baik terhadap pengetahuan siswa dalam pembelajaran pendidikan jasmani olahraga dan kesehatan serta antusiasnya siswa terhadap pendidikan jasmani olahraga dan kesehatan. Hal tersebut ditunjukkan dengan nilai rata-rata posttest sebesar $92,51 \%$ yang persentasenya lebih besar dari nilai rata-rata pre-test yang hanya 18,33\%. Dengan demikian, penekanan aspek literasi pada siswa sekolah dasar dapat digunakan dalam pembelajaran pendidikan jasmani olahraga dan kesehatan.
\end{abstract}

Kata kunci: literasi siswa, pendidikan jasmani, zoom meeting.

\begin{abstract}
In the current pandemic era, learning between teachers and students is less effective because teaching and learning activities take place at home. Community service activities in the form of Kuliah Kerja Nyata Tematik described in this paper aim to increase student interest in learning, as well as make it easier for teachers, students and parents even though the learning process takes place at home. The activities are in the form of learning physical education, sports and health, which are carried out online through the Zoom Meeting application, which emphasizes literacy. The method in this community service activity uses descriptive quantitative research with random sampling technique and uses a pretest-posttest design. The results of the activity showed that there was a good increase in students' knowledge in learning physical education of sports and health as well as students' enthusiasm for physical education of sports and health. This is indicated by the posttest average value of $92.51 \%$, which is greater than the pre-test average value of only $18.33 \%$. Thus, the emphasis on literacy aspects in elementary school students can be used in learning physical education, sports and health.
\end{abstract}

Keywords: physical education, student literacy, zoom meeting.

Volume 2, Nomor 2, Oktober 2021 | 127

Improving Students' Literacy Skills in Learning Physical Education, Sports and Health through Zoom

Meetings

Intan Risky Nur Apristi, Rina Maryanti

https://doi.org/10.26874/jakw.v2i2.133 


\section{Introduction}

Education is needed by a child in various environments such as school, family and residence. Because, education is a place to find, bring up, and develop the potential that exists in every child which is carried out intentionally and planned through a process of guidance activities, guidance to children so that they have intelligence, emotional and spiritual intelligence to be equipped to live life in a community environment in the future. (Ramdhani, 2017). In Law no. 20 of 2003 Article 1 paragraph 37h of education in Indonesia requires efforts to develop good planning, approaches, and strategies, which are regulated in curriculum regulations. The curriculum for primary and secondary education is required to include physical education (Mustafa and Dwiyogo, 2020). Physical education, sports and health are subjects that involve physical activity and habituation of a healthy lifestyle so that it can stimulate physical growth, health and physical fitness, abilities and skills and balanced individual development (Supriatna and Wahyupurnomo, 2015).

While the goals of physical education in sports are to develop psychomotor, cognitive, and affective potential (Yuliawan, 2016), while according to M. Furqon Hidayatullah which states that the purpose of physical education is to develop student potential through physical activity. Therefore, there is no education that does not have a pedagogical goal, and no education is complete without physical education, because movement as a physical activity is the basis for humans to know the world and themselves which naturally develop in line with the times. Therefore, physical education has a mission to produce educated people (Widodo, 2018). That way a teacher needs to emphasize literacy in learning physical education, sports and health, because literacy can be interpreted as an ability or skill that every student must have (Akbar, 2017) to read various phenomena in everyday life as an analytical, critical and analytical learning environment. reflective (Nurkamilah, Nugraha, \& Sunendar, 2018), literacy is also not just reading and writing, literacy is meaningful in practice and social relations related to knowledge, language, and culture (Teguh, 2020).

Therefore, physical literacy includes continuous learning that enables individuals to achieve their goals in building their knowledge and potential and to fully participate and communicate in the wider community (Herlina and Suherman, 2020). With the problems and expectations described above, the researchers want to study further related to student literacy skills, especially in learning physical education sports and health in a study entitled "Improving Literacy Ability in Learning Physical Education in Sports and Health" with the aim of knowing 
Jurnal Abdimas Kartika Wijayakusuma ISSN 2716-3512 (Online) ISSN 2721-0367 (Print)
This work is licensed under a Creative Commons Attribution-ShareAlike 4.0 International License.

whether an increase in students by emphasizing literacy in learning physical education, sports and health. This study uses a quantitative descriptive approach using a pre-experimental method in the form of a one-group pretest-posttest design. The results showed an increase in the average value after the material and explanations were given in the form of powerpoint through google zoom media.

\section{Method}

This activity was held at SD Negeri 2 Majalengka Kulon. The method in this community service activity uses a pre-experimental design method with a random sampling technique and one group pretest-posttest type. In this activity the researcher was fully involved in data collection. The data collection technique in this community service activity is by distributing a questionnaire in the form of a google form to students to find out students' views on the material "Improving Student Literacy Skills in Learning Physical Education, Sports and Health through Zoom Meetings". The population in this activity is 35 students at SDN 2 Majalengka Kulon 2. The sample used in this activity is 12 students and in this activity is divided into 2 stages, the first is the pretest, where students fill out the questionnaire that has been given, after the pretest data appears. presentations are made through the Zoom meeting application, after the lecture is over, students fill out the same questionnaire with the posttest results. The instrument used was a two-choice Likert scale (yes or no). The data obtained will be processed and concluded into the results that have been obtained.

\section{Results and Discussion}

However, before carrying out the activity, the researcher asked for permission from the Village Head and the Principal of the SD Negeri 2 Majalengka Kulon for this community service event to take place as shown in Figure 1.
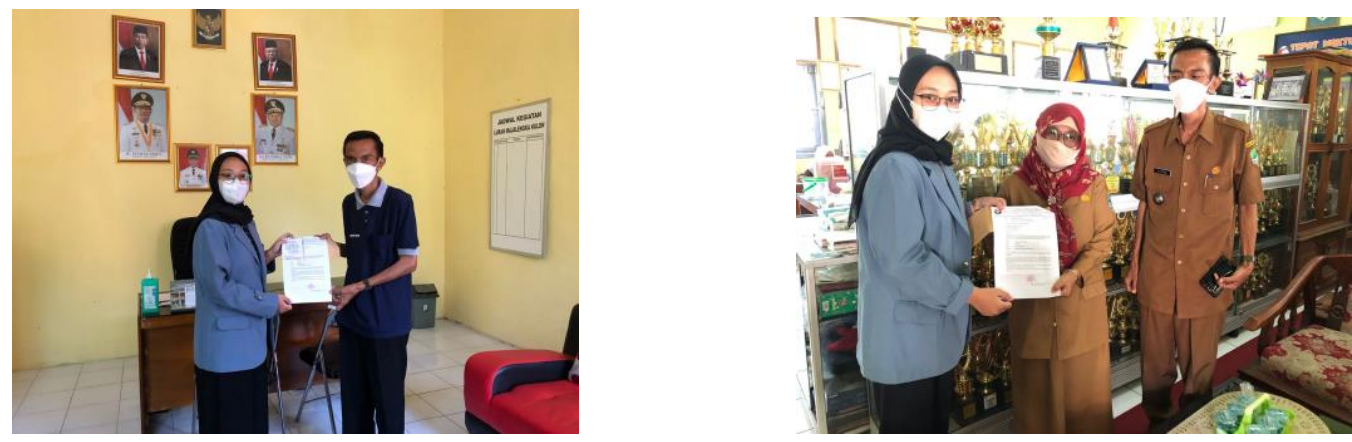

Figure 1. Meeting with Village Head and the Principal of SD Negeri 2 Majalengka Kulon

Volume 2, Nomor 2, Oktober 2021| 129

Improving Students' Literacy Skills in Learning Physical Education, Sports and Health through Zoom Meetings 
Jurnal Abdimas Kartika Wijayakusuma ISSN 2716-3512 (Online) ISSN 2721-0367 (Print)
This work is licensed under a Creative Commons Attribution-ShareAlike 4.0 International License.

Learning activities at SD Negeri 2 Majalengka Kulon are carried out online or online. Learning activities are carried out through the zoom meeting application and google form as a medium to support learning (Herlina \& Suherman, 2020). Before doing the lesson, the researcher gave directions first as an introduction to the zoom application and the google form, the directions were given to students and parents, so that people continue to monitor their children even though they are in online learning using the zoom meeting application or google form.

After conducting the directions, the researcher distributed a questionnaire to the 12 students as their knowledge of literacy in sports and health education learning or you could say the questionnaire was a pretest. Then after the pretest data was obtained, the researcher began to explain literacy in sports and health physical education learning through the zoom meeting application by presenting a material made in the form of a powerpoint. After doing the learning, the researcher redistributed the same questionnaire as in the pretest, so that it could be seen how the development of students' literacy skills in learning physical education, sports and health or it could be said as posttest data.

Table 1. Student Pretest and Posttest Results.

\begin{tabular}{|c|c|c|c|c|}
\hline Numb & Question & Pretest & Posttest & Increased \\
\hline 1. & Do you like learning sports? & $100 \%$ & $100 \%$ & $0 \%$ \\
\hline 2. & Do you know what literacy is? & $33.3 \%$ & $100 \%$ & $66.6 \%$ \\
\hline 3. & Do you know literacy in sports? & $8.3 \%$ & $100 \%$ & $91.7 \%$ \\
\hline 4. & Do you know sports science? & $16.7 \%$ & $100 \%$ & $83.3 \%$ \\
\hline 5. & Do you know sports Physiology? & $0 \%$ & $91.7 \%$ & $91.7 \%$ \\
\hline 6. & Do you know Sports Medicine? & $16.7 \%$ & $91.7 \%$ & $75 \%$ \\
\hline 7. & Do you know Sport Nutrition? & $8.3 \%$ & $91.7 \%$ & $83.4 \%$ \\
\hline 8. & Do you know Sport Psychology? & $16.7 \%$ & $100 \%$ & $83.3 \%$ \\
\hline 9. & $\begin{array}{l}\text { Do you know Sport } \\
\text { Biomechanic? }\end{array}$ & $0 \%$ & $75 \%$ & $75 \%$ \\
\hline \multirow{2}{*}{10.} & $\begin{array}{l}\text { Can you reading this pattern ? } \\
\qquad \stackrel{ \pm}{\times 3}\end{array}$ & \multirow{2}{*}{$0 \%$} & \multirow{2}{*}{$75 \%$} & \multirow{2}{*}{$75 \%$} \\
\hline & $\times 2$ & & & \\
\hline
\end{tabular}


The results show several discussion points:

1) Result number 1 does not show an increase, but the percentage is still at $100 \%$, which means that it shows the student's fondness for learning physical sports and health

2) In number 2 , there is an increase of $66.6 \%$ when the material has been given and explained.

3) Numer. 3 shows an increase of $91.7 \%$ when the material has been given and explained.

4) Number 4 shows an increase of $83.3 \%$ when the material has been given and explained.

5) Number 5 shows an increase of $91.7 \%$ when the material has been given and explained.

6) Number 6 shows an increase of $75 \%$ when the material has been given and explained.

7) Number 7 shows an increase of $83.4 \%$ when the material has been given and explained.

8) Number 8 shows an increase of $83.3 \%$ when the material and explanation has been given.

9) Number 9 shows an increase of $75 \%$ when the material and explanation has been given.

10) And number 10 also shows an increase of $75 \%$ when the image has been explained and presented.

Table 1 shows that the knowledge of students who initially did not know more about physical education in sports and health and after the implementation of literacy in their learning students could find out more about physical education in sports and health. Like the case of students in sports science, there are still many students who do not know, at first $16.7 \%$ and after learning through zoom meetings which emphasize literacy in learning students are able to get more information and their knowledge increases to $100 \%$ and from there it can be seen a very good increase that is equal to $83.3 \%$. The research results from the whole that the average value of the pretest is $18.33 \%$ and the average value of the posttest is $92.51 \%$.

\section{Conclusion}

From this activity it can be concluded that students' interest in physical education in sports and health is very enthusiastic, where in the new curriculum education literacy needs to be instilled in every learning as well as sports education. This can be seen from the very good results, namely the posttest average value of $92.51 \%$, which is greater than the pretest average value of $18.33 \%$. After inculcating literacy such as reading, writing and scientific literacy in physical education, sports and health, even though only through the zoom meeting application, students' abilities improved better. 


\section{Acknowledgment}

We acknowledge to the principal and students of SD Negeri 2 Majalengka Kulon who was involved in the activity in the form Kuliah Kerja Nyata Tematik.

\section{References}

Akbar, A. 2017. Membudayakan literasi dengan program 6M di sekolah dasar. Jurnal Pendidikan Sekolah Dasar, 3(1), 42-52.

Herlina, H. \& Suherman, M. 2020. Potensi Pembelajaran Pendidikan Jasmani Olahraga Dan Kesehatan (PJOK) Di Tengah Pandemi Corona Virus Disease (Covid)-19 Di Sekolah Dasar. Tadulako Journal Sport Sciences And Physical Education, 8(1), 1-7.

Kelana, J. B., Wulandari, M. A. \& Wardani, D. S. 2021. Penggunaan Aplikasi Zoom Meeting di Masa Pandemi Covid-19 Pada Pembelajaran Sains. Jurnal Elementary: Kajian Teori Dan Hasil Penelitian Pendidikan Sekolah Dasar, 4(1), 18-22.

Mustafa, P. S. \& Dwiyogo, W. D. 2020. Kurikulum Pendidikan Jasmani, Olahraga, dan Kesehatan di Indonesia Abad 21. JARTIKA Jurnal Riset Teknologi Dan Inovasi Pendidikan, 3(2), 422-438.

Nurkamilah, M., Nugraha, M. F. \& Sunendar, A. 2018. Mengembangkan literasi matematika siswa sekolah dasar melalui pembelajaran matematika realistik Indonesia. Jurnal THEOREMS, 2(2), 70-79.

Ramdhani, M. A. 2017. Lingkungan pendidikan dalam implementasi pendidikan karakter. Jurnal Pendidikan UNIGA, 8(1), 28-37.

Supriatna, E. \& Wahyupurnomo, M. A. 2015. Keterampilan guru dalam membuka dan menutup pelajaran pendidikan jasmani olahraga dan kesehatan di SMAN Se-Kota Pontianak. Jurnal Pendidikan Jasmani Indonesia, 11(1).

Teguh, M. 2020. Gerakan literasi sekolah dasar. Jurnal Pendidikan Dasar Flobamorata, 1(2), $1-9$.

Widodo, A. 2018. Makna dan Peran pendidikan jasmani dalam pembentukan insan yang melek jasmaniah/ter-literasi jasmaniahnya. Motion: Jurnal Riset Physical Education, 9(1), 53-60.

Yuliawan, D. 2016. Pembentukan karakter anak dengan jiwa sportif melalui pendidikan jasmani olahraga dan kesehatan. JOURNAL OF SPORTIF, 2(1), 101-112. 